Krzysztof Krasowski

Poznań

\title{
Abp Józef Teofil Teodorowicz jako mąż stanu
}

Ks. Józef Teofil Teodorowicz w dniu 2 III 1902 r. we Lwowie przyjął sakrę biskupią z rąk kard. Jana Puzyny i objął rządy w archidiecezji lwowskiej obrządku ormiańskiego. Była to archidiecezja nietypowa, licząca ok. 5,5 tysiąca wiernych, obsługiwanych przez 18-25 duchownych, odpowiadająca średniej wielkości parafii obrządku łacińskiego. Stosunkowo niewielki zakres obowiązków duszpasterskich pozwalał mu aktywnie angażować się w życie publiczne.

Jego poglądy kształtowały się pod wpływem doktryny szeroko rozumianego nurtu narodowego, którą umiejętnie łączył z nauką społeczną Kościoła katolickiego. W młodości należał do Ligi Narodowej, a następnie do blisko związanego z Narodową Demokracją (endecją) wschodniogalicyjskiego Narodowo-Chrześcijańskiego Stronnictwa Ludowego. Po zamachu majowym z 1926 r. publicznie pochwalał poglądy Romana Dmowskiego i jego projekt budowy Obozu Wielkiej Polski. W latach 30. XX wieku, rozczarowany endecją, ewoluował w kierunku Frontu Morges Ignacego Paderewskiego, z którym pozostawał w bardzo dobrych stosunkach.

Arcybiskup ormiański imponował swoją aktywnością w działalności narodowej i społecznej. Wypada zgodzić się z następującą opinią wyrażoną w literaturze: „Można powiedzieć, że nie było ważniejszego wydarzenia narodowego bez udziału abpa Teodorowicza. Był wszędzie tam, gdzie trzeba było zabrać głos w decydujących dla polskiego społeczeństwach kwestiach, gdzie rozstrzygać się miały istotne dla ówczesnych czasów problemy - nie tylko z zakresu życia religijnego"'.

Abp Teodorowicz był urodzonym politykiem i parlamentarzystą, organizatorem prasy katolickiej, obdarzonym także talentem pisarskim i dziennikarskim. Z jego inicjatywy od 1897 r. zaczął ukazywać się we Lwowie „Ruch Katolicki”, a w 1900 r. „Przedświt”. Pisywał artykuły do tych czasopism, ujawniając duży talent literacki.

Od 1902 r. był członkiem wiedeńskiej Izby Panów, wygłaszając na tym forum w $1917 \mathrm{r}$. dwa słynne przemówienia, w których odważnie domagał się wskrzeszenia polskiej państwowości. Był również posłem do galicyjskiego Sejmu Krajowego i członkiem Rady Szkolnej Krajowej. Wywierał duży wpływ na życie polityczne Galicji tego okresu, m.in. bezpośrednio przyczyniając się do obalenia projektu nowej ordynacji wyborczej w $1913 \mathrm{r}$. i ustąpienia namiestnika Galicji Michała Bobrzyńskiego².

Swoją działalnością daleko wykraczał poza Galicję, pełniąc przed 1914 r. rolę łącznika między duchowieństwem z Wielkopolski a Stolicą Apostolską, często interweniując

\footnotetext{
${ }^{1}$ K. Krasowski, Biskupi katoliccy II Rzeczypospolitej. Stownik biograficzny, Poznań 1996, s. 292.

2 Tamże, s. 293.
} 
w obronie polskich interesów w Kurii rzymskiej, m.in. w okresie słynnych strajków szkolnych w zaborze pruskim. W dobie plebiscytu na Górnym Śląsku podjął się wspólnie z biskupem krakowskim Adamem Stefanem Sapiehą trudnej misji przeciwdziałania niekorzystnym dla sprawy polskiej skutkom działalności ówczesnego nuncjusza w Warszawie abp. Achillesa Rattiego, od 1922 r. papieża Piusa XI, a przede wszystkim biskupa wrocławskiego kard. Adolfa Bertrama. Abp Ratti jeszcze w marcu 1920 r. został mianowany przez papieża Naczelnym Komisarzem Kościelnym dla obszarów plebiscytowych. W polskiej opinii uchodził za osobę bardziej sprzyjającą interesom niemieckim, niemającą wiary w polską wygraną. Oliwy do ognia dolało „Arcypasterskie zarządzenie” z 21 XI 1920 r. kard. Bertrama, w którym dozwolono księżom na udział w kampanii propagandowej wyłącznie za zgodą proboszczów parafii. Okólnik, pozornie dotyczący obu narodowości, w rzeczywistości godził w polskie interesy, ponieważ na Górnym Śląsku niższe duchowieństwo podlegało proboszczom, którzy w $80 \%$ byli narodowości niemieckiej. Tak sformułowane zarządzenie praktycznie oddawało w ręce niemieckiego duchowieństwa kierownictwo akcją agitacyjną. Fakt ten poruszył polskie społeczeństwo. Całe odium krytyki spadło na nuncjusza, z którego upoważnienia to zarządzenie zostało wydane. W dniu 30 XI 1920 r. na posiedzeniu Sejmu podjęto rezolucję wzywającą rząd, aby wszczął starania o uchylenie okólnika kard. Bertrama. W dyskusji padały głosy żądające odwołania abp. Rattiego, a nawet zerwania stosunków dyplomatycznych z Watykanem. Jeszcze tego samego dnia rząd wystąpił z prośbą do Episkopatu Polski o interwencję w Kurii rzymskiej. W grudniu 1920 r. abp Teodorowicz z bp. Sapiehą udali się do Watykanu. Uzyskali tu od sekretarza Stanu kard. Pietro Gasparriego oświadczenie, że księżom dozwolone jest swobodne wypowiadanie swych przekonań na zgromadzeniach bez zgody zwierzchnich władz kościelnych. Do uchylenia okólnika kard. Bertrama jednak nie doszło. Wpływy niemieckie w Kurii rzymskiej okazały się silniejsze od nacisków polskiego Ppiskopatu ${ }^{3}$. Misja watykańska obu hierarchów przyniosła jednak ważny skutek - odwołanie wiosną 1921 r. abp. Rattiego z Nuncjatury warszawskiej. Fakt ten stanowił jedno z głównych źródeł napiętych relacji, także osobistych, między abp. Rattim i abp. Teodorowiczem, a bp Sapieha zapłacił później wysoką cenę, bowiem za pontyfikatu Piusa XI nie doczekał się kapelusza kardynalskiego.

W pierwszych latach po odzyskaniu przez Polskę niepodległości, abp Teodorowicz nie wycofał się z życia politycznego. W lutym 1919 r. został posłem do Sejmu Ustawodawczego i swoistym łącznikiem między posłami w sutannach a Episkopatem. A warto przypomnieć, że duchowni w tym parlamencie stanowili aż 9\% (ogółem 32 mandaty) ogółu posłów. Starał się koordynować - nie bez trudności - ich działalność przez wspólne narady przed każdym posiedzeniem Sejmu, odbywane w jego warszawskim miesz$\mathrm{kaniu}^{4}$. Na posiedzeniach plenarnych prowadził liczne polemiki i utarczki w obronie praw religii z „osobistymi wrogami Pana Boga” na lewicy: Kazimierzem Czapińskim

\footnotetext{
${ }^{3}$ K. Krasowski, Między Warszawa a Watykanem. Episkopat Polski wobec rzadu i Stolicy Apostolskiej 1918-1939, w: Szkice z dziejów papiestwa, t. 1, red. I. Koberdowa, J. Tazbir, Warszawa 1889, s. 284 nn.

${ }_{4}$ Tenże, Episkopat katolicki w II Rzeczypospolitej. Myśl o ustroju państwa - postulaty - realizacja, Warszawa-Poznań 1992, s. 82.
} 
i Józefem Putkiem. Uczestniczył też w pracach nad projektem konstytucji marcowej, proponując m.in. zapis przyznający biskupom miejsce w Senacie w charakterze wirylistów. Wobec zdecydowanego sprzeciwu nuncjusza abp. Rattiego, wycofał się z tego pomysłu .

Poza parlamentem abp Teodorowicz starał się też oddziaływać na politykę rządów tego okresu pełniąc funkcję doradcy premiera Leopolda Skulskiego oraz ministra spraw zagranicznych Eustachego Sapiehy ${ }^{6}$.

W listopadzie 1922 r. zarówno arcybiskup ormiański, tak jak i bp A. S. Sapieha, zostali wybrani senatorami z ramienia "Chjeny”, ale musieli zrzec się mandatu w lutym 1923 r. na wyraźne żądanie papieża Piusa XI. Nuncjusz Ratti, a następnie papież Pius XI, w przeciwieństwie do swojego poprzednika Benedykta XV, bardzo krytycznie odnosił się do aktywnej działalności politycznej duchowieństwa i jego udziału w pracach stronnictw partyjnych. Prawdziwe zgorszenie wywoływała w nim postawa abp. Teodorowicza, któremu nawet zarzucał celowe osłabianie wśród biskupów obowiązku posłuszeństwa wobec Stolicy Apostolskiej7. Wpływ na to miały polskie doświadczenia papieża i osobiste animozje. Pius XI nie zapomniał abp. Teodorowiczowi, iż w słynnym sporze o prymasostwo między metropolitą gnieźnieńskim abp. Edmundem Dalborem a metropolitą warszawskim abp. Aleksandrem Kakowskim, którego popierał, abp Teodorowicz opowiedział się po stronie abp. Dalbora uzyskując wsparcie wszystkich biskupów galicyjskich ${ }^{8}$. Czarę goryczy przelały okoliczności pierwszej w niepodległej Polsce ogólnokrajowej konferencji Episkopatu w Gnieźnie w sierpniu 1919 r. To z inicjatywy abp. Teodorowicza nie zaproszono na nią nuncjusza Rattiego. Za jego też sprawą konferencja wystosowała niepublikowany list do Benedykta XV, w którym biskupi zajęli krytyczne stanowisko wobec idei zawarcia w przyszłości konkordatu z Watykanem, za czym zdecydowanie opowiadał się abp Ratti ${ }^{9}$.

Przebieg i rezultaty zjazdu w Gnieźnie przyniosły porażkę nuncjuszowi i metropolicie warszawskiemu, który nawet do grobu św. Wojciecha nie przyjechał z błahego powodu. Abp Ratti dał wyraz swojemu niezadowoleniu w liście skierowanym do kard. Gaspariiego, w którym krytykował postawę abp. E. Dalbora i polskich biskupów oraz treść przyjętych wówczas uchwał. Odpowiedzialnością za to obarczał abp. Teodorowicza, który zdaniem nuncjusza był przywódcą politykujących biskupów i narzędziem partii opozycyjnych w walce z rządem. Abp Ratti podkreślał, że ormiański hierarcha wywiera ujemny wpływ na abp. Dalbora i bp. A. S. Sapiehę, wzbudzając ich nieufność do Watykanu. Jedynym hierarchą opierającym się „wpływom galicyjskim”, był abp. A. Kakowski, który zdaniem nuncjusza pozostawał wierny Stolicy Apostolskiej i zawsze występował po jego stronie w sporach z polskimi biskupami. Na zakończenie listu nuncjusz prosił kardynała, aby ten, wykorzystując pobyt metropolitów gnieźnieńskiego i warszawskiego

\footnotetext{
5 Tamże, s. 239, przypis 62.

6 Tamże, s. 80.

7 Tamże, s. 82 nn.

8 Tamże, s. 40 nn.

9 K. Krasowski, Między Warszawa a Watykanem, s. 295 nn.
} 
w Rzymie, umocnił abp. Kakowskiego w jego dotychczasowej postawie oraz zwrócił uwagę abp. E. Dalborowi na niestosowne zachowanie abp. J. Teodorowicza ${ }^{10}$.

Napięte stosunki między nuncjuszem A. Rattim a abp. Teodorowiczem raczej nie podważały jego pozycji lwowskiego hierarchy w Episkopacie. Nuncjusze w tym okresie nie cieszyli się dobrą opinią wśród polskich biskupów. Byli szanowani jako reprezentanci Kurii rzymskiej, ale niepożądani jako pośrednicy w stosunkach z rządem i Watykanem. Potwierdza to ocena następcy abp. Rattiego, jako nuncjusza w Warszawie, abp. Lorenza Lauriego, dotychczasowego nuncjusza w Peru, sformułowana przez abp. Teodorowicza w liście do prymasa w związku zakończeniem watykańskiego dyplomaty misji na gruncie polskim w styczniu $1927 \mathrm{r}$. W piśmie tym zarzucał abp. Lauriemu rozbijanie solidarności Episkopatu, mieszanie się w sprawy wewnętrzne diecezji, bezzasadne skargi na biskupów w Watykanie, ale i przed rządem polskim. Bardzo mocno podkreślał też niechęć abp. Lauriego do rządów obozu narodowego. Abp Teodorowicz miał tu zapewne na myśli bezprecedensowe wywiady nuncjusza, których udzielił on prasie na przełomie roku 1923/24, ostro atakując najpierw stanowisko rządu Chjeno-Piasta w sprawie reformy rolnej, aby następnie wyrazić ogromne zadowolenie $\mathrm{z}$ faktu objęcia urzędu premiera przez Władysława Grabskiego ${ }^{11}$.

W relacjach ze swoim oponentem metropolitą Aleksandrem Kakowskim, od grudnia 1919 r. kardynałem, za czasów prymasa Dalbora miał jego pełne poparcie za postawę w sprawie sporu o prymasostwo. Abp Teodorowicz nie żywił sympatii do kard. Kakowskiego, obdarzając go wielce wymownym epitetem: „nasze Bizancjum”, jako synonimem gorliwego lojalizmu, czy wręcz serwilizmu wobec władz państwowych. Kard. Kakowski nie pozostawał mu dłużny, mówiąc o metropolicie ormiańskim, że to wielki kaznodzieja, ale słaby polityk. Zarzucał mu, iż w stosunkach z Kurią rzymską bardziej reprezentował interesy swojej partii niż stanowisko Episkopatu ${ }^{12}$.

Bez względu na napięte relacje z nuncjuszami i kard. Kakowskim, niepodważalny jest fakt, iż do schyłku lat 20. XX w. ormiański hierarcha odgrywał ogromną rolę w pracach konferencji Episkopatu Polski. Od 1919 r. wchodził w skład Komitetu Biskupów, a od 1928 r. Komisji Prawnej, organu faktycznie kierującego polskim Kościołem. Za rządów prymasa Edmunda Dalbora był głównym ekspertem do spraw politycznych w Episkopacie. Na sesjach krajowych zawsze przedstawiał analizę aktualnej sytuacji politycznej w kraju, a jego oceny i wnioski stanowiły podstawę uchwał podejmowanych przez gremium biskupów. Po zamachu majowym w 1926 r., tę funkcję przejął początkowo kard. A. Kakowski, a następnie prymas kard. August Hlond. Pozycja abp. Teodorowicza w Episkopacie stopniowo ulegała marginalizacji. Ten fakt miał swoją wymowę, ilustrując przegrupowania dokonujące się w łonie Episkopatu po maju 1926 r. ${ }^{13}$

Abp Teodorowicz był znany ze swojej niechęci, a nawet wrogości do Józefa Piłsudskiego i jego rządów. Wprawdzie w genezie przewrotu majowego dostrzegał i winę

\footnotetext{
10 Tenże, Episkopat katolicki, s. 42.

11 Tenże, Między Warszawa a Watykanem, s. 289.

12 Tamże, s. 318.

${ }^{13}$ K. Krasowski, Biskupi katoliccy, s. 294.
} 
Endecji, która jego zdaniem swoim niedołęstwem i olbrzymimi błędami, często moralnymi, sprowokowała te wydarzenia, to jednak oceniał je w bardzo ostrych słowach pisząc: „Ten zamach oddał Polskę w ręce jednego obłąkanego człowieka i klikę ludzi z małymi wyjątkami pozbawionymi wszelkiej znajomości rządzenia, przy zupełnym braku poczucia odpowiedzialności, a za to przy żądzy władzy okupionej choćby kosztem Polski"14. Wprawdzie, jak i Marszałek, publicznie krytykował praktykę rządów parlamentarnych domagając się silnej władzy, ale opartej na wartościach narodowych i zasadach katolickich. Ideę silnego państwa, głoszoną przez obóz sanacyjny, oceniał jako niebezpieczeństwo dyktatury i totalizacji życia publicznego. Taki system rządów określał wprost nazwą „państwa pogańskiego”, opartego jedynie na kulcie siły złożonej w ręce tych, którzy osobiste interesy podszyli pod interesy państwa, hasła wolnościowe zamienili w fikcję, a naród zniewolili do oddawania czci pojedynczym osobom. Tej wizji przeciwstawiał ideał państwa chrześcijańskiego, którym rządzi duch prawdziwej demokracji, wspartej nie na walce klas, nienawiści i przywilejach, ale na zasadzie równości wszystkich wobec prawa. Odrzucając ideę państwową Piłsudskiego, abp Teodorowicz zdecydowanie opowiadał się za prymatem narodu podkreślając, że rządzący są tylko sługami, a nie jego tyranami. Dlatego dawał wyraz ogromnemu zaniepokojeniu pisząc: "Zdaje się, jakoby dzisiaj wielu chciało ukryć w cień samą nawet nazwę naród, lękając się o to, by nie przyćmiewała ona przypadkiem państwa. Czymże jednak jest państwo bez narodu? Czymże jest innym, jak nie jakąś wielką salą, zamkniętą przed publicznością, w której ścianach rozlega się echo zaledwie kilku ludzi, sprzęgniętych węzłami wzajemnej adoracji i wzajemnych interesów. Nie można państwa oddzielać od narodu. Nie wolno na rzecz państwa konfiskować pojęcia narodu [...]. Naród może żyć bez państwa [...], ale nie może istnieć państwo bez narodu"15.

Po maju 1926 r., abp Teodorowicz podejmował próby zjednania oponentów rządu w Episkopacie dla idei poparcia reformowanego przez Romana Dmowskiego ruchu narodowego i projektu Obozu Wielkiej Polski. Słynna broszura Dmowskiego pt.: Kościót, Naród, Państwo, w której autor kierował nurt narodowy w łożysko nauki katolickiej, spotkała się z entuzjastyczną recenzją ormiańskiego arcybiskupa. Wyraził on zadowolenie, że Dmowski „dojrzał ścisły związek pomiędzy Kościołem a uzdrowieniem narodowej duszy". Przy tej okazji abp Teodorowicz przeprowadził bezwzględną krytykę demokracji parlamentarnej, przyrównując Polskę z lat 1918-1926 do domu budowanego na piasku, zamiast na skale, który w każdej chwili mógł się zawalić. Lekarstwo na to widział w silnym rządzie, opartym na duchu narodowym i zasadach katolickich. Ujawnił przy tym swoje zafascynowanie osobą Benito Mussoliniego mówiąc o nim: „Jest to człowiek opatrznościowy nie tylko dla swej ojczyzny, ale dla obecnego powojennego świata. To wychowawca narodu w duchu religijnym [sic!], który zrozumiał, że zasady chrześcijańskie stanowią jedyną obronę przed komunizmem i masonerią" ${ }^{16}$. W konkluzji

${ }^{14}$ List abp. J. Teodorowicza do I. Paderewskiego z lipca 1930 r., w: Archiwum Polityczne Ignacego Paderewskiego, t. 3, oprac. H. Janowska, Cz. Madajczyk, Wrocław 1974, s. 177 nn.

${ }^{15}$ J. Teodorowicz, Państwo chrześcijańskie a państwo pogańskie, Lwów 1931, s. $10 \mathrm{nn}$.

16 Tenże, O ducha narodu polskiego, Poznań 1927, s. 32 nn. 
abp Teodorowicz podkreślał: „Dzisiaj złączyć się nam potrzeba w jeden wielki obronny obóz narodowy, zespolić w jednym pospolitym ruszeniu w obronie naszej kultury chrześcijańskiej i organicznych podstaw chrześcijańskich ideałów, które są tak ściśle sprzężone z samym organizmem narodu i państwa - jego żywotnością, jego rozwojem i przyszłością"17. W świetle tej wypowiedzi poparcie przez abp. Teodorowicza koncepcji Obozu Wielkiej Polski wydaje się bezdyskusyjne.

Przed wyborami parlamentarnymi w 1928 r., abp Teodorowicz starał się pozyskać biskupów do wydania listu pasterskiego, wzywającego wiernych do oddawania głosów na Endecję. We współpracy z R. Dmowskim opracował pierwotną wersję tego dokumentu. Napotkał jednak na zdecydowany sprzeciw prymasa kard. A. Hlonda. Zmienił on tekst orędzia usuwając z niego wszystko to, co wskazywałoby katolikom jasną drogę do głosowania na określone listy. W efekcie tych zabiegów, w zbiorowym liście pasterskim z 6 XII 1927 r. biskupi nie polecali wiernym wprost żadnej partii politycznej. Wzywano jedynie do oddawania głosów na obóz katolickonarodowy. Odezwa ta wprawdzie była dość enigmatyczna, ale z jej tonu można wnioskować, iż koncepcję tego ugrupowania traktowano raczej nie jako klasyczny sojusz wyborczy kilku partii, ale szerszą platformę zrzeszającą wszystkich katolików ponad podziałami partyjnymi. Świadczy o tym bezwzględna krytyka w liście „partyjniactwa”. Jeśli do tego dodać sformułowany w tym dokumencie postulat rewizji konstytucji w kierunku zapewnienia Polsce „silnego ustroju i władzy, bardziej niż dotąd od wpływów partyjnych niezależną"18, to uderza tu pewna zbieżność z hasłami i taktyką wyborczą obozu sanacyjnego.

Wybory do Sejmu z 4 III 1928 r. przyniosły najwięcej mandatów listom bloku rządowego BBWR (28\%). Endecja poniosła druzgocącą klęskę, uzyskując zaledwie 8,5\% mandatów, o wiele mniej także od PPS (14,4\%), Bloku Mniejszości Narodowych $(12,4 \%)$ i PSL "Wyzwolenie" $(9,2 \%)^{19}$.

Nie udało się zbudować jednolitego bloku katolickonarodowego. W lakonicznej formie skomentował ten fakt wybitny publicysta o. Jan Urban SJ pisząc: „Głos Episkopatu o stworzenie wielkiego obozu katolickiego, dla oparcia całej polityki przyszłego Sejmu na podstawach katolickich, nie odniósł sukcesu" ${ }^{20}$. Było to jednoznaczne przyznanie się do porażki taktyki Episkopatu, sformułowanej w liście pasterskim z grudnia $1927 \mathrm{r}$.

W ocenach wyników wyborów dominował ton zaskoczenia, rozczarowania i niezadowolenia, wyrażany przede wszystkim przez biskupów zaangażowanych na rzecz obozu narodowego. Lwowski hierarcha ormiański z wielkim rozgoryczeniem stwierdzał: „Przecież z tej katolickiej Polski wyszła większość parlamentarna Kościołowi wroga. Nastąpiło zdumienie, jak się to stać mogło, ale samo to zdumienie świadczy, żeśmy byli zaskoczeni przez wroga, który niepostrzeżenie działał w ukryciu" ${ }^{21}$. Można w tych

\footnotetext{
17 Tamże.

18 K. Krasowski, Episkopat katolicki, s. 98.

19 Tamże, s. 103.

${ }^{20}$ J. Urban, Po wyborach, PP, 44(1928), t. 178, s. 6.

21 K. Krasowski, Episkopat katolicki, s. 106.
} 
słowach znaleźć nutę krytyki wobec udziału kard. A. Hlonda w redakcji listu pasterskiego z $1927 \mathrm{r}$.

Głęboki konflikt w stosunkach z prymasem, a także w całym Episkopacie, wywołała sprawa brzeska. Abp Teodorowicz wraz z abp. A. S. Sapiehą domagali się natychmiastowego wystąpienia $\mathrm{w}$ formie listu otwartego do prezydenta, piętnującego praktyki aresztowań posłów i przywódców opozycji oraz stosowanych wobec nich środków w twierdzy brzeskiej. Zdecydowanie byli temu przeciwni kard. A. Hlond i kard. A. Kakowski ${ }^{22}$. Abp Teodorowicz wraz z abp. Sapiehą opracowali projekt takiego listu, w którym pisano: „W sprawie brzeskiej skumulowały się wszystkie niezdrowe kierunki. Wszystkie fałszywe drogi od chwili powstania państwa polskiego odbiły się w nim (tzn. Brześciu) i dlatego wstrząsnął on do głębi sumieniem całego społeczeństwa i Polski. Rozumie nasze społeczeństwo, że od rozwiązania tej sprawy zależy, po jakiej drodze potoczą się dalsze losy Polski. Dlatego wskazując na Brześć, jako na jeden z symbolów rozstrojów, dostrzegamy czynniki odpowiedzialne. Jeśliby sprawa ta, tak bolesna niezmiernie, miała znaleźć rozwiązanie, jakiego nawet przypuścić nie chcemy, to jest gdyby się nie zakończyła i sankcją prawa, wówczas biada nam i gniew Boży musiałby spaść na tę nieszczęsną krainę, która zaparła się wielkiej idei sprawiedliwości”23.

Prymas nie chciał jednak słyszeć o tym projekcie. W odpowiedzi abp A. S. Sapieha zdobył się na krok ostateczny oświadczając, że w tej sytuacji, wspólnie z abp. Teodorowiczem czują się zwolnieni z obowiązku solidarności wobec Episkopatu. Abp Teodorowicz w liście do prymasa, tłumacząc swoją decyzję, pisał: „Jak gdyby szatan tu chciał nas rozstroić. Pozory i znowu pozory są tak fatalne, że można dziś mówić o kryzysie Konferencji Episkopatu"24. W zakończeniu otwarcie wyznał, że od dłuższego czasu biskupi informowali go, że prymas uważa jego działalność za szkodliwą i chce go pozbawić wpływów. Przytoczył znaną mu treść listu kard. Hlonda do kard. Kakowskiego, w którym prymas ostrzegał, żeby nie dawać odzewu „politykowi, którego ciasny horyzont polityczny nie dozwala mu się wznieść do szerszego horyzontu" ${ }^{25}$. Arcybiskup ormiański nie chciał polemizować z tym osądem, ale pytał z wyrzutem: „Dlaczego teraz takie deptanie mnie i w jakim celu?"26

Ostatecznie znaleziono kompromis. Jego owocem był słynny list pasterski prymasa kard. Hlonda z 23 IV 1932 r. „O chrześcijańskie zasady życia państwowego” ${ }^{27}$.

Po zażegnaniu konfliktu brzeskiego, abp Teodorowicz nadal często przedstawiał prymasowi swoje oceny sytuacji politycznej w Polsce, ale nie miały one już większego wpływu na decyzje podejmowane przez kard. A. Hlonda. Prymas niewątpliwie doceniał przymioty kapłańskie arcybiskupa ormiańskiego, ale zdecydowanie nie podzielał jego poglądów politycznych. Konsekwentnie realizował jeden z głównych celów pontyfikatu Piusa XI - odpolitycznienie Kościoła. Widział w tym środek do integracji Episkopatu,

\footnotetext{
22 Tamże, s. 117 nn.

23 Tamże, s. 119.

24 Tamże.

25 Tamże.

26 Tamże.

27 Tamże, s. 121 nn.
} 
promując biskupów co najmniej neutralnych wobec rządu, a marginalizując tych, którzy nie kryli swojej krytyki wobec rządzących. W tej drugiej grupie znalazł się też abp Teodorowicz.

Choć Ormianin, ale z niezwykle głęboko rozbudzonym poczuciem polskości, abp. Józef Teodorowicz był urodzonym politykiem i parlamentarzystą, wybitnym publicystą, kaznodzieją i mówcą przyrównywanym do ks. Piotra Skargi. Swoje poglądy na naród i państwo potrafił prezentować z bogatą argumentacją i pięknym językiem. Należał bez wątpienia do grona najwybitniejszych członków polskiego Episkopatu z czasów II Rzeczypospolitej. 